\title{
PROFILE OF THE DEMAND ASSISTED BY A TEAM OF ORAL AND MAXILLOFACIAL SURGEONS IN THE CITY OF CUIABÁ, BRAZIL: A TIME-SERIES STUDY
}

\author{
PERFIL DA DEMANDA ATENDIDA POR UMA EQUIPE DE CIRURGIÕES \\ BUCOMAXILOFACIAL EM CUIABÁ, BRASIL: UM ESTUDO DE SÉRIE TEMPORAL
}

\author{
Artur Cunha VASCONCELOS ${ }^{1}$; Luís Ricardo Machado MAGALHÃES ${ }^{2}$; \\ Walbert de Andrade VIEIRA ${ }^{3}$; Ítalo de Macedo BERNARDINO ${ }^{4}$; Ricardo Pedro da SILVA ${ }^{5}$; \\ Caio Luiz LINS-CANDEIRO ${ }^{6}$; Luiz Renato PARANHOS ${ }^{6}$ \\ 1. Department of Dentistry, Morgana Potrich College, Mineiros, Goiás, Brazil; E-mail: acvodonto@ hotmail.com 2. Private Clinic, \\ Cuiabá, Mato Grosso, Brazil; 3. Department of Dentistry, Federal University of Sergipe, Aracaju, Sergipe, Brazil; 4. Department of \\ Dentistry, Paraíba State University, Campina Grande, Paraíba, Brazil; 5. Department of Bucomaxillo Facial Surgery, Federal University \\ of Uberlândia, Uberlândia, MG, Brazil 6. Department of Preventive and Social Dentistry, Federal University of Uberlândia, Uberlândia,
} MG, Brazil.

\begin{abstract}
The present study aimed to characterize the procedures performed by the oral and maxillofacial surgery team at a Brazilian reference hospital in a Brazilian city, as well as to describe the time trend of the number of services related to different types of surgery. It is a time-series study that assessed the data from the medical records of patients assisted at a reference hospital in a city in the state of Mato Grosso (Brazil), from 2011 to 2017. The data were assessed using descriptive statistical analysis, correspondence analysis (CA), and time trend analysis. A total of 1488 medical records were evaluated, the majority of which corresponded to male patients (59\%), extractions were the most performed procedures (46.2\%), local anesthesia was the most applied technique $(50.3 \%)$, and the procedures were mostly performed in an outpatient environment $(53.2 \%)$. There was a decreasing global time trend $\left(\mathrm{R}^{2}=0.248 ; \mathrm{p}<0.001\right)$. Male patients are the most assisted in hospital care and are particularly related to more invasive procedures; there is also a decreasing curve of assistance over the years in the oral and maxillofacial surgery and traumatology service of the hospital studied.
\end{abstract}

KEYWORDS: Hospital care. Dental care. Hospital dental team. Epidemiological survey.

\section{INTRODUCTION}

The presence of dentists in the hospital environment is necessary and indispensable (MATTEVI et al., 2011), and it is provided by law (BRASIL, 2012). The number of multi-professional residency programs grows all over Brazil and worldwide, providing the hospital with a crosssectional view of the patient, in which health is seen as a whole (DA MOTTA; PACHEDO, 2014; MIRANDA, 2017). The importance of dentists in hospital environments is extensively described in the literature, for either the maintenance of an oral environment free from pathogens that may trigger further systemic complications (SOUSA et al., 2014; EPSTEIN, 2014; MIRANDA, 2017) or the early detection and treatment of cysts and tumors in the oral cavity (MORAIS et al., 2006; BRODY et al., 2013).

Among the dental residency programs, the Oral and Maxillofacial Surgery and Traumatology (OMFST) is one of the most traditional. It has an essential role, especially in cases of patients with systemic conditions that prevent treatment in the outpatient environment (BELL, 2007), as well as every service focusing on diagnosis and the surgical and adjuvant treatment of diseases, traumas, congenital and acquired lesions and anomalies of the masticatory system and auxiliaries, and associated craniofacial structures (BRASIL, 2002; BELL, 2007).

Characterizing the surgical procedures more commonly performed in a given hospital, identifying the months with higher concentration of care services, and investigating time variations may produce useful information for assessing service needs, reorienting care practices, strategic planning, predicting expenditures with personnel and materials, and developing health prevention and promotion programs.

After a critical literature review, it was verified that several studies have focused on characterizing the patients assisted in hospital care and have described the different forms of management (RAPOSO et al., 2011; OLUSANYA et al., 2015; BARBOSA et al., 2017). However, 
time-series studies related to this topic are rare. Therefore, this study aimed to characterize the services performed in a Brazilian reference hospital and to describe the time trend of the number of services related to different types of surgery.

\section{MATERIAL AND METHODS}

\section{Protocol and ethical criteria}

All Brazilian and international guidelines related to research ethics involving human beings were respected. The project was approved by an Independent Human Research Ethics Committee (Report \#2.097.096 / Certificate of presentation for ethical appreciation: 65676317.1.0000.5165). The Strengthening the Reporting of Observational Studies in Epidemiology (STROBE) statement (Von Elm et al., 2007) was used to aid the research performance and the reporting of results obtained.

\section{Study design and settings}

This was a time-series study of cases assisted in a reference hospital located in a Brazilian capital city. It was cohort for being a longitudinal study that analyzed service rates over time (from February 2011 to February 2017) and historical because it used data contained in the medical records of female and male patients without restriction of age group.

The hospital selected for this study is reference for an estimated population of 585,367 inhabitants living in the city of Cuiabá, which is the capital of the Brazilian state of Mato Grosso. After analyzing the database of the institution, the medical records of the patients were analyzed consecutively.

The cases that were considered significant for the study included services related to biopsies, extractions, implants, management and control of infections, and orthognathic, reconstructive, and trauma surgeries.

\section{Data collection}

Prior to the research, a pilot study and calibration procedures were performed to test the method proposed and standardize the way of interpreting the information available in the medical records of patients. In the pilot study, two researchers were submitted to training and calibration exercises for data collection.

A form was developed specifically for this study from the information contained in the medical records of patients. These records are made by employees of the institution who hold the position of residents. Considering that the institution does not have a digital information system yet, every record was read and the information matching the objectives of the study were transcribed by the researchers, who were trained and calibrated to fill out the form. A convenience sample was used for data collection as well as the start date is justified by the availability of medical records.

The variables were selected to allow characterizing the services performed in hospital care over the period studied, including: 1) Number of surgical cases assisted; 2) Sex; 3) Classification of procedures (extraction, biopsy, trauma, reconstruction, implant, orthognathic surgery); 4) Location of the procedures (surgery center or outpatient clinic); 5) Type of anesthesia (general, local, local with sedation).

\section{Data analysis}

Initially, a descriptive statistical analysis was performed. Then, Pearson's chi-square test was applied to explore the association among the categorical variables studied (sex of the patient, surgery classifications, location of the procedure, and type of anesthesia used). The significance level was set at $5 \%(\mathrm{p}<0.05)$. The results of the association between surgery classifications and type of anesthesia used were presented graphically by means of a statistical method that is fairly new, known as correspondence analysis (CA). This technique is rather promising for analyzing data from studies in the field of oral and maxillofacial surgery and traumatology, considering it produces a biplot graphic that allows identifying whether the variables are associated and how the categorical variables are associated, which is not always evident using the traditional statistical methods (HAIR et al., 2009; BERNARDINO et al., 2017).

Lastly, the time trend analysis (MONTGOMERY et al., 2015) was used to evaluate the data by producing polynomial regression models, which aimed particularly to find the curve that best fits the data and to describe the relationship between the number of procedures performed (dependent variable) and the time/month studied (independent variable). This allows identifying whether the number of surgical procedures presented stable, increasing, or decreasing trends during the observation period, which is important for assessing the need for health services, reorientation of care practices, and the reallocation of human and financial resources.

The following polynomial regression models were tested: a) linear; b) quadratic; c) exponential. The selection of the best model was determined by analyzing the scatter plot based on the coefficient of determination $\left(\mathrm{R}^{2}\right)$, to which the 
values closer to 1 indicate better quality of adjustment and residue analysis (assumption of real homoscedasticity). When two models were similar to the statistical point of view, the simpler model (inferior order) was selected to prevent a serial correlation between periods (months) (MONTGOMERY et al., 2015). The IBM SPSS Statistics software (SPSS for Windows, version 20.0, Armonk, NY: IBM Corp.) was used for data analysis, considering a $95 \%$ confidence interval.

\section{RESULTS}

During the period studied (from February 2011 to February 2017), 1488 medical records of patients were analyzed. Table 1 shows the distribution of the cases according to sex, surgery classification, location of the procedure, and type of anesthesia used. Most patients were men $(\mathrm{n}=892$; $59.9 \%$ ). According to Table 2, a statistically significant association was verified between the sex of the patient and the type of procedure performed $(\mathrm{p}<0.001)$. The proportion of procedures such as biopsies $(\mathrm{n}=226 ; 51.8 \%)$, implant surgery $(\mathrm{n}=65$; $79.3 \%)$, and reconstructive surgery $(\mathrm{n}=53 ; 51.5 \%)$ was higher for the group of women, while the proportion of procedures such as extractions $(\mathrm{n}=$ $482 ; 70.2 \%)$, management and control of infection $(\mathrm{n}=10 ; 76.9 \%)$, trauma $(\mathrm{n}=108 ; 78.3 \%)$, and orthognathic surgery $(\mathrm{n}=15 ; 51.7 \%)$ was higher for the group of men.

Table 1. Distribution of the cases according to sex, surgery classification, location of the procedure, and type of anesthesia used.

\begin{tabular}{|c|c|c|}
\hline Variables & $\mathbf{n}$ & $\%$ \\
\hline \multicolumn{3}{|l|}{ Sex } \\
\hline Male & 892 & 59.9 \\
\hline Female & 596 & 40.1 \\
\hline \multicolumn{3}{|l|}{ Surgery classification } \\
\hline Biopsy & 436 & 29.3 \\
\hline Extraction & 687 & 46.2 \\
\hline Implant & 82 & 5.5 \\
\hline Infection & 13 & 0.9 \\
\hline Orthognathic & 29 & 1.9 \\
\hline Reconstructive & 103 & 6.9 \\
\hline Trauma & 138 & 9.3 \\
\hline \multicolumn{3}{|l|}{ Location of the procedure } \\
\hline Outpatient clinic & 791 & 53.2 \\
\hline Surgery center & 695 & 46.8 \\
\hline \multicolumn{3}{|l|}{ Type of anesthesia used } \\
\hline Local anesthesia & 749 & 50.3 \\
\hline Local anesthesia + Sedation & 334 & 22.4 \\
\hline General anesthesia & 405 & 27.2 \\
\hline Total & 1488 & 100.0 \\
\hline
\end{tabular}

Figure 1 shows the biplot graphic from the correspondence analysis (CA) between the type of surgery performed and the type of anesthesia applied $(\mathrm{p}<0.001)$. A statistically significant association was found $(p<0.001)$. Local anesthesia or local anesthesia associated with sedation was typically used for procedures such as implant and extraction, while general anesthesia was applied more often in cases of trauma, orthognathic, and reconstructive surgeries. A heterogeneous pattern of the type of anesthesia used was observed in the cases of biopsy, and management and control of infection 
Table 2. Association between the sex of the patient and characteristics of the surgical procedures performed.

\begin{tabular}{|c|c|c|c|c|}
\hline \multirow{3}{*}{ Variables } & \multicolumn{2}{|c|}{ Sex } & \multirow{3}{*}{$\frac{\text { Total }}{\text { n }(\%)}$} & \multirow{3}{*}{ p-value } \\
\hline & Male & Female & & \\
\hline & n $(\%)$ & n $(\%)$ & & \\
\hline Surgery classification & & & & $<0.001 *$ \\
\hline Biopsy & $210(48.2)$ & $226(51.8)$ & $436(100.0)$ & \\
\hline Extraction & $482(70.2)$ & $205(29.8)$ & $687(100.0)$ & \\
\hline Implant & $17(20.7)$ & $65(79.3)$ & $82(100.0)$ & \\
\hline Infection & $10(76.9)$ & $3(23.1)$ & $13(100.0)$ & \\
\hline Orthognathic & $15(51.7)$ & $14(48.3)$ & $29(100.0)$ & \\
\hline Reconstructive & $50(48.5)$ & $53(51.5)$ & $103(100.0)$ & \\
\hline Trauma & $108(78.3)$ & $30(21.7)$ & $138(100.0)$ & \\
\hline Location of the procedure & & & & 0.067 \\
\hline Outpatient clinic & $457(57.8)$ & $334(42.2)$ & $791(100.0)$ & \\
\hline Surgery center & $434(62.4)$ & $261(37.6)$ & $695(100.0)$ & \\
\hline Type of anesthesia used & & & & 0.889 \\
\hline Local anesthesia & $446(59.5)$ & $303(40.5)$ & $749(100.0)$ & \\
\hline Local anesthesia + Sedation & $204(61.1)$ & $130(38.9)$ & $334(100.0)$ & \\
\hline General anesthesia & $242(59.8)$ & $163(40.2)$ & $405(100.0)$ & \\
\hline
\end{tabular}

Note. Pearson's chi-square test; * Statistically significant association at $\mathrm{p}<0.05$.

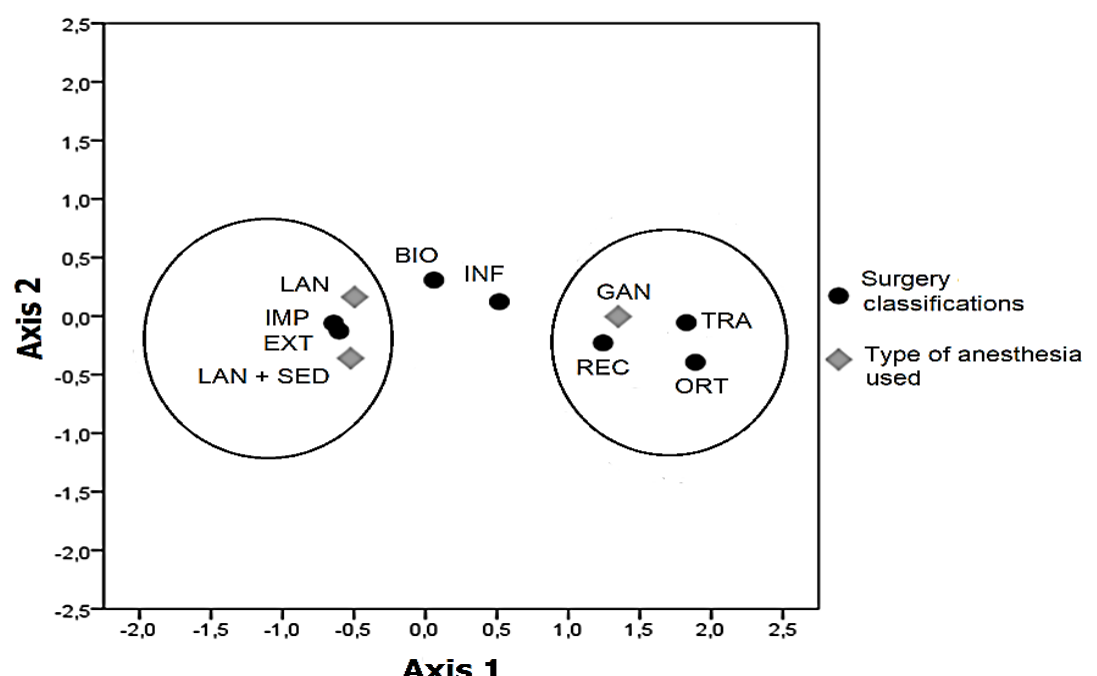

Figure 1. Biplot graphic from the correspondence analysis (CA) between the type of surgery performed and the type of anesthesia applied $(\mathrm{p}<0.001)$.

Figure 2 presents the time series for the total number of surgical procedures performed from February 2011 to February 2017. According to Table 3, the global time trend was decreasing $\left(\mathrm{R}^{2}=\right.$ $0.248 ; \mathrm{p}<0.001)$, meaning that the number of surgeries presented a declining trend. When analyzing the trend according to types of surgeries, a stable trend was found (i.e., without significant variation over time) for the procedures of orthognathic surgery $\left(\mathrm{R}^{2}=0.018 ; \mathrm{p}=0.256\right)$, trauma $\left(R^{2}=0.016 ; p=0.184\right)$, and management and control of infection $\left(\mathrm{R}^{2}=0.023 ; \mathrm{p}=0.199\right)$. A decreasing trend was observed for the other types of procedures. As for implant procedures, the trend was decreasing, but unstable $\left(\mathrm{R}^{2}=0.292 ; \mathrm{p}<\right.$ $0.001 *)$, indicating that certain points of the time series showed greater intensification of this type of service. 


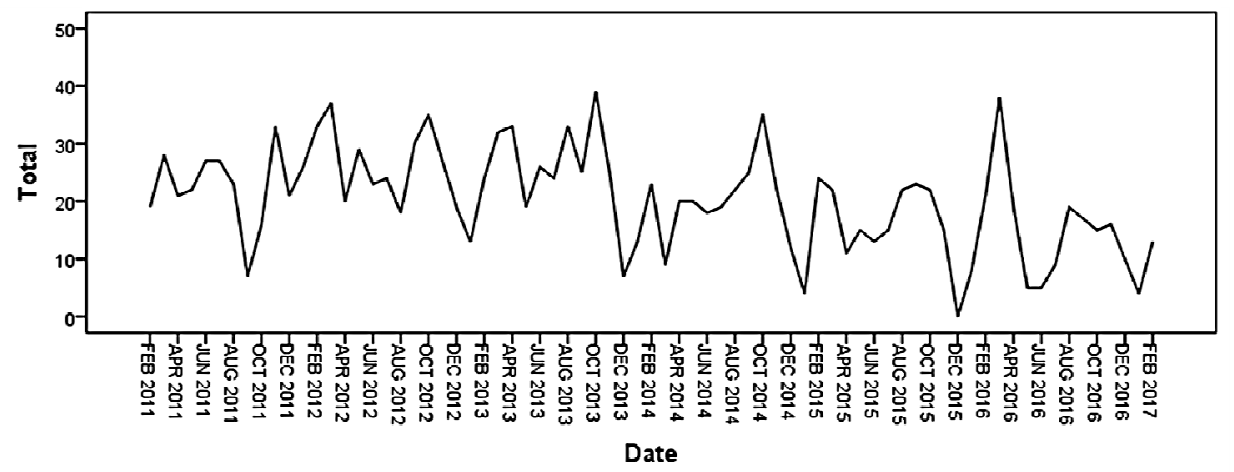

Figure 2. Time series for the total number of surgical procedures performed from February 2011 to February 2017.

Table 3. Results of the temporal trend analysis for a series of surgical procedures performed monthly between the years 2011 and 2017.

\begin{tabular}{|c|c|c|c|c|c|}
\hline Variables & $\begin{array}{c}\text { Number of } \\
\text { cases }\end{array}$ & Model & $\mathbf{R}^{2}$ & $\begin{array}{c}\text { p- } \\
\text { valor }\end{array}$ & Trend \\
\hline Total & 1488 & $\begin{array}{c}Y=22,184-0,192 X- \\
0,004 X^{2}\end{array}$ & 0,248 & $\begin{array}{c}< \\
0,001 *\end{array}$ & Decreasing \\
\hline \multicolumn{6}{|c|}{ Types of surgeries } \\
\hline Biopsy & 436 & $\begin{array}{c}Y=6,567-0,045 X- \\
0,001 X^{2}\end{array}$ & 0,114 & $0,015^{*}$ & Decreasing \\
\hline Extraction & 687 & $\begin{array}{c}Y=10,687-0,100 X- \\
0,003 X^{2}\end{array}$ & 0,246 & $\begin{array}{c}< \\
0,001 *\end{array}$ & Decreasing \\
\hline Implant & 82 & $\begin{array}{c}Y=0,766-0,036 X+ \\
0,001 X^{2}\end{array}$ & 0,292 & $\begin{array}{c}< \\
0,001 *\end{array}$ & Decreasing, , but unstable \\
\hline Infection & 13 & $Y=0,178+0,003 X$ & 0,023 & 0,199 & Stable \\
\hline Orthognathic & 29 & $Y=0,397-0,004 X$ & 0,018 & 0,256 & Stable \\
\hline Reconstructive & 103 & $\begin{array}{c}Y=1,666-0,022 X- \\
0,001 X^{2}\end{array}$ & 0,170 & $0,001 *$ & Decreasing \\
\hline Trauma & 138 & $Y=1,890+0,011 X$ & 0,016 & 0,184 & Stable \\
\hline
\end{tabular}

\section{DISCUSSION}

The present study aimed to characterize the services performed in a Brazilian reference hospital and to describe the time trend of the number of services related to different types of surgery. Retrospective studies are crucial and may be useful to reorganize the service team of the hospital according to the demand received besides serving as a basis for planning educational actions. One of the strengths of the present study is to be the first research developed for this purpose in the studied region. The application of the time trend analysis in this scenario also represents a strength once the allows to better explore the database and generates evidence capable of supporting the decision-making process.

Recent data show an increasing presence of oral and maxillofacial surgeons in the hospital environment, especially motivated by the development of residency programs for training these professionals (ROCHA; FERREIRA, 2014). The role of the oral and maxillofacial surgeon as a dental specialty is very broad, as they are responsible for the management of post-traumatic patients, the performance of biopsies in the oral cavity, excision and resection of tumors, orthognathic surgeries, and management of infections (BRASIL, 2002). This role may be observed in the literature (CUSTÓDIO et al., 2016; VASCONCELOS et al., 2017; VASCONCELOS et al., 2018) and in the results of the present study, in which over one thousand people were assisted by the Oral and Maxillofacial Surgery and Traumatology (OMFST) service of the hospital selected and several types of procedures were performed, thus showing the importance of this specialty in the hospital environment.

Men were most often assisted by the OMFST team in the present study. These data 
corroborate other similar studies that show men as the majority in surgical services within hospital environments (OLUSANYA et al., 2015; BARBOSA et al., 2017). It is worth noting that besides representing the majority of services, men are associated with more invasive procedures such as extractions, post-traumatic care, orthognathic surgeries, and treatment of infections, while women are related to procedures such as biopsies and implants. These results confirm the difference in profiles between the sexes observed in other states. For instance, men are always the majority in accidents involving trauma and extractions (OLUSANYA et al., 2015; BARBOSA et al., 2017; VASCONCELOS et al., 2018), while women performed more rehabilitation (THUKRAL et al., 2016) or elective procedures (CAMARGO et al., 2009). Although decreasing over the years, it is concerning that extraction was the most performed procedure. Because of the numerous consequences, extracting a dental unit is only recommended as a last treatment option, but there is still a popular habit of performing extractions as an option for restorative or endodontic procedures (RUSSEL et al., 2013).

In dental outpatient clinics, the use of local anesthesia is safe and extensively promoted, and it may be used in any routine procedure (SU et al., 2014). For special cases of patients with high anxiety levels, the American Dental Association (ADA) has established protocols for decreasing anxiety and pain using sedation (AMERICAN DENTAL ASSOCIATION, 2016). In patients assisted in hospital environments, the more severe clinical condition may motivate more frequent preoperative anxiety conditions, for which the use of sedative agents is required. General anesthesia is another anesthetic mode, which induces the loss of consciousness of the patient and it is used mostly in cases of higher surgical complexity (AMERICAN DENTAL ASSOCIATION, 2016). The results shown in the present study corroborate such definitions, which observed the use of local anesthesia with or without sedation only in simpler procedures such as extractions, while general anesthesia was used in more complex procedures such as orthognathic, trauma, and reconstructive surgeries.

The heterogeneity regarding the anesthetic mode for procedures such as biopsies and control of infections may be explained by the fact that there are different management forms depending on the clinical condition of the patient (CUSTÓDIO et al., 2016); for instance, more severe infections such as Ludwig's Angina should be treated under general anesthesia (CANDAMOURTY et al., 2012) and other periapical abscesses may be solved using local anesthesia (SIQUEIRA JR; RÔÇAS, 2013). Regardless of the anesthetic technique used, the professionals should always respect the systemic condition of the patient, following the recommendations proposed by the American Society of Anesthesiologists (ASA) (AMERICAN SOCIETY OF ANESTHESIOLOGISTS, 2014).

The present study is observational and therefore its main limitation is not identifying the confounding factors that might be related to the associations found. The present study is observational and therefore its main limitation is not identifying the confounding factors that might be related to the associations found. On the other hand, the present study has contributed to the scientific literature for being the first research to characterize the services of a reference hospital in the city of Cuiabá, Brazil, as well as to use a different statistical analysis with a fairly new and promising method known as correspondence analysis (CA).

\section{CONCLUSION}

Men are the majority in hospital care and they are related to more invasive procedures such as extractions and post-traumatic care. Moreover, a decreasing curve of service was observed over the years in the OMFST of the hospital studied.

RESUMO: O presente estudo teve como objetivo caracterizar os procedimentos realizados pela equipe de cirurgia bucomaxilofacial em um hospital brasileiro de referência de uma cidade brasileira, bem como descrever a tendência temporal da quantidade de atendimentos relacionados a diferentes tipos de cirurgia. Trata-se de um estudo de série temporal que avaliou os dados dos prontuários de pacientes atendidos em um hospital de referência em uma cidade do estado do Mato Grosso (Brasil) entre os anos de 2011 e 2017. Os dados foram avaliados por meio de uma análise estatística descritiva, teste de Análise de correspondência (AC) e análise de tendência temporal. No total, 1488 registros foram avaliados, dos quais a maioria correspondia a pacientes do sexo masculino (59\%), exodontias foram os procedimentos mais realizados $(46,2 \%)$, a técnica anestésica mais empregada foi a local $(50,3 \%)$ e os procedimentos foram realizados em sua maioria em âmbito ambulatorial $(53,2 \%)$. A tendência temporal global foi decrescente do tempo global $(\mathrm{R} 2=0,248 ; \mathrm{p}<0,001)$. Os 
pacientes do sexo masculino são os mais assistidos no atendimento hospitalar e estão particularmente relacionados a procedimentos mais invasivos; há também uma curva decrescente de assistência ao longo dos anos no serviço de cirurgia oral e bucomaxilofacial do hospital estudado.

PALAVRAS-CHAVE: Cuidados hospitalares. Cuidado odontológico. Equipe hospitalar odontológica. Levantamento epidemiológico.

\section{REFERENCES}

AMERICAN DENTAL ASSOCIATION. Guidelines for the Use of Sedation and General Anesthesia by Dentists, 2016. Disponível em: http//www.ada.org/. Acesso em: 11 mar. 2018.

AMERICAN SOCIETY OF ANESTHESIOLOGISTS. ASA Physical Status Classification System, 2014. Disponível em: http//www.asahq.org/. Acesso em: 11 mar. 2018.

BARBOSA, K. G. N.; BERNADINO, Í.M.; D'AVILA, S.; FERREIRA, E. F. E.; FERREIRA, R.C. Systematic review and meta-analysis to determine the proportion of maxillofacial trauma resulting from different etiologies among children and adolescents. Oral and Maxillofacial Surgery. v. 21, n. 2, p. 131-145, 2017. https://doi.org/10.1007/s10006-017-0610-9

BELL, R. B. The role of oral and maxillofacial surgery in the trauma care center. Journal of Oral and Maxillofacial Surgery, v. 65, n. 12, p. 2544-2553, 2007. https://doi.org/10.1016/j.joms.2007.02.003

BERNARDINO, Í. M.; SANTOS, L. M.; FERREIRA, A. V. P.; LIMA, T. L. M. A.; NÓBREGA, L. M.; D'AVILA, S. Multiple correspondence analysis as a strategy to explore the association between categories of qualitative variables related to oral-maxillofacial trauma and violent crimes at the community level.

International Journal of Oral and Maxillofacial Surgery, v. 47, n. 3, p. 339-344, 2018.

https://doi.org/10.1016/j.ijom.2017.08.001

BRASIL. Câmara dos Deputados - Congresso Nacional. Projeto de Lei n. ${ }^{\circ} 2.776-\mathrm{B} 13$ de fevereiro de 2008. Estabelece a obrigatoriedade da presença de profissionais de odontologia em UTI [Internet]. Brasília, DF; 2012. Disponível em: http://www.camara.gov.br/ Acesso em: 03 mar.2018.

BRASIL. Resolução CFO no 22 de 27/12/2001. Anúncio e exercício das especialidades odontológicas e sobre cursos de especialização. Diário Oficial da União, 25 jan, Seção I, 2002.

BRODY, S.; OMER, O.; MCLOUGHLIN, J.; STASSEN, L. The dentist's role within the multi-disciplinary team maintaining quality of life for oral cancer patients in light of recent advances in radiotherapy. Journal of the Irish Dental Association, v. 59, n. 3, p. 137-146, 2013.

CAMARGO, M. B.; DUMITH, S. C.; BARROS, A. J. D. Regular use of dental care services by adults: patterns of utilization and types of services. Cadernos de Saúde Pública, v. 25, n. 9, p. 1894-1906, 2009.

https://doi.org/10.1590/S0102-311X2009000900004

CANDAMOURTY, R.; VENKATACHALAM, S.; BABU, M.R.; KUMAR, G.S. Ludwig's Angina - An emergency: A case report with literature review. Journal of Natural Science, Biology, and Medicine, v. 3, n. 2, p. 206-208, 2012. https://doi.org/10.4103/0976-9668.101932

CUSTÓDIO, A. L. N.; COTA, R. M. E.; OLIVEIRA, L. J. Odontogenic infections in a dental emergency care unit: Eleven-year epidemiological analysis. Brazilian Journal of Oral Sciences. v. 15, n. 3, p. 173-175, 2016. https://doi.org/10.20396/bjos.v15i3.8649600 
DA MOTTA, L. B.; PACHECO, L. C. Integrating medical and health multiprofessional residency programs: the experience in building an interprofessional curriculum for health professionals in Brazil. Education for Health (Abingdon), v. 27, n. 1, p.83-88, 2014. https://doi.org/10.4103/1357-6283.134331

EPSTEIN, N. E. Multidisciplinary in-hospital teams improve patient outcomes: A review. Surgical Neurology International, v. 5, n. 7, p. 295-303, 2014. https://doi.org/10.4103/2152-7806.139612

HAIR, J. F.; BLACK, W. C.; BABIN, J. B.; ANDERSON, R. E.; TATHAM, R. L. Multivariate data analysis. 6th Ed. Upper Saddle River, NJ, Prentice-Hall, p. 1-30, 2009.

MATTEVI, G. S.; FIGUEIREDO, D. R.; PATRÍCIO, Z. M.; RATH, I. B. S. A participação do cirurgiãodentista em equipe de saúde multidisciplinar na atenção à saúde da criança no contexto hospitalar. Ciência \& Saúde Coletiva, v. 16, n. 10, p. 4229-4236, 2011.

MIRANDA, A. F. The Dental Surgeons in the Hospital and their Professional Areas in Brazil: Hospitalization Units, Surgical Centers and Intensive Care Units. Journal of Community Medicine \& Health Education, v. 7, n. 1, p. 1-7, 2017.

MONTGOMERY, D. C.; JENNINGS, C. L.; KULAHCI, M. Introduction to Time Series Analysis and Forecasting. 2nd Ed. Hoboken, NJ, John Wiley \& Sons, p. 672, 2015.

MORAIS, T. M. N.; SILVA, A.; AVI, A. L. R. O.; SOUZA, P. H. R.; KNOBEL, E.; CAMARGO, L. F. A. Importance of Dental Work in Patients under Intensive Care Unit. Revista Brasileira de Terapia Intensiva, v. 18, n. 4, p. 412-417, 2006.

OLUSANYA, A. A.; ADELEYE, A. O.; ALADELUSI, T. O.; FASOLA, A. O. Updates on the epidemiology and pattern of traumatic maxillofacial injuries in a Nigerian university teaching hospital: a 12-month prospective cohort in-hospital outcome study. Craniomaxillofacial Trauma \& Reconstruction., v. 8, n. 1, p. 50-58, 2015.

RAPOSO, A.; MUNÕZ, C.; PREISLER, G.; SALINAS, F. Maxillofacial surgical procedure performed under general anesthesia in the Base Hospital of Valdivia. International Journal of Oral and Maxillofacial Surgery, v. 40, n. 10, p. 1157-1158, 2011. https://doi.org/10.1016/j.ijom.2011.07.445

ROCHA, A. L.; FERREIRA, E. F. Hospital dentistry: the role of the dentist in multidisciplinary teams in tertiary care. Arquivos em Odontologia. v. 50, n. 4, p. 154-160, 2014.

https://doi.org/10.7308/aodontol/2014.50.4.01

RUSSELL, S. L.; GORDON, S.; LUKACS, J. R.; KASTE, L. M. Sex/Gender differences in tooth loss and edentulism: historical perspectives, biological factors, and sociologic reasons. Dental Clinics of North America, v. 57, n. 2, p. 317-337, 2013. https://doi.org/10.1016/j.cden.2013.02.006

SIQUEIRA JUNIOR, J. F.; RÔÇAS, I. N. Microbiology and treatment of acute apical abscesses. Clinical Microbiology Reviews, v. 26, n. 2, p. 255-273, 2013. https://doi.org/10.1128/CMR.00082-12

SOUSA, L. V. S.; PEREIRA, A. F. V.; SILVA, N. B. S. A atuação do cirurgião-dentista no atendimento hospitalar. Revista de Ciências da Saúde, v. 16, n. 1, p. 39-45, 2014.

SU, N.; LIU, Y.; YANG, X.; SHI, Z.; HUANG, Y. Efficacy and safety of mepivacaine compared with lidocaine in local anaesthesia in dentistry: a meta-analysis of randomized controlled trials. International Dental Journal, v. 64, n. 2, p. 96-107, 2014. https://doi.org/10.1111/idj.12087 
THUKRAL, R.; KUMAR, A.; PRASANT, M. C.; PUNJABI, K. M.; PALIWAL, A.; PATEL K. Assessment of Patients Referred to Specialty Dental Hospitals for Dental Implant Procedure: A Retrospective Cohort Analysis. The Journal of Contemporary Dental Practice, v. 17, n. 6, p. 470-475, 2016.

https://doi.org/10.5005/jp-journals-10024-1874

VASCONCELOS, A. C.; ABURAD, C.; LIMA, I. F. P.; SANTOS S. M. M.; FREITAS FILHO, S. A. J.;

FRANCO, A.; RODE, S. M.; PARANHOS, L. R. A scientific survey on 1550 cases of oral lesions diagnosed in a Brazilian referral center. Anais da Academia Brasileira de Ciências, v. 89, n. 3, p. 1691-1697, 2017. https://doi.org/10.1590/0001-3765201720170006

VASCONCELOS, A. C.; DIAS, J. C.; WIPPEL, M. P. R.; VIEIRA, W. A.; MENESES, I. S.; RIBEIRO, M. A. G.; PARANHOS, L. R. Epidemiological aspects of cranioencephalic trauma at Cuiabá Municipal Hospital, Brazil. International Journal of Odontostomatology, v. 12, n. 1, p. 29-34, 2018.

https://doi.org/10.4067/S0718-381X2018000100029

VON ELM E.; ALTMAN, D. G.; EGGER, M.; POCOCK, S. J.; GØTZSCHE, P. C.; VANDENBROUCKE, J. P. et al. Strengthening the Reporting of Observational Studies in Epidemiology (STROBE) statement: guidelines for reporting observational studies. BMJ, v. 335, n. 7624, p. 806-808, 2007.

https://doi.org/10.1136/bmj.39335.541782.AD 